УДК 004.9.005.95

Рибидайло А. А., к.т.н., с.н.c., (ORCID: 0000-0002-6156-469X);

Прокопенко О. С.,

(ORCID: 0000-0002-5482-0317);

Турейчук А. М., к.т.н.,

(ORCID: 0000-0002-4837-500X);

Руденська Г. В.,

(ORCID: 0000-0002-4719-3765)

Центр воєнно-стратегічних досліджень Національного університету оборони України імені Івана Черняховського, Київ

\title{
Ключові показники ефективності управління персоналом збройних сил
}

Резюме. Розглянуто питання обгрунтування та формування ключових показників ефективності управління персоналом Збройних Сил України.

Ключові слова: ключовий показник ефективності; система кадрового менеджменту; персонал Збройних Сил; DRMIS.

Постановка проблеми. Основою будякої організаційної структури $є$ людські ресурси. Яку б ідеальну організаційну структуру не мала би організація, за відсутності необхідної чисельності персоналу, браку висококваліфікованих кадрів, вона не зможе ефективно виконувати завдання за призначенням. Отже, головним пріоритетом кожної організації $\epsilon$ підбір кадрів та управління персоналом.

Останнім часом сформувався особливий напрям у діяльності організацій - контролінг (від англ., to control - контролювати, управляти). У найбільш загальному вигляді концепція контролінгу $є$ одним із способів стратегічного управління підприємством, що охоплює широкий спектр технологій управління, загальними рисами яких є формалізація цільових показників, планування i контроль досягнення цілей. Технологія контролінгу включає:

визначення цілей діяльності;

відображення цих цілей у системі показників;

встановлення цільових значень показників на певний період (планування); регулярний контроль (вимір) фактичних значень показників;

аналіз і виявлення причин відхилень фактичних значень показників від планових; прийняття на цій основі управлінських рішень щодо мінімізації відхилень.

Цільове завдання контролінгу побудова на підприємстві ефективної системи прийняття, реалізації, контролю та аналізу управлінських рішень.

До того ж використовується система збалансованих показників (СЗП), складовою якої $€$ сукупність ключових показники ефективності (КПЕ). У міру свого розвитку контролінг, як управлінський механізм, поступово дезінтегрувався в окремий напрям контролінг персоналу.

На сьогодні технології контролінгу широко використовуються на бізнеспідприємствах, які приносять прибуток. Оскільки військове відомство є неприбутковою бюджетною організацією, формування КПЕ, зокрема щодо управління персоналом Збройних Сил, потребує врахування цієї обставини. Використання КПЕ за основними напрямами кадрового менеджменту у системі підтримки прийняття рішень (СППР) надасть можливість керівництву коригувати план реалізації узгодженої стратегії, тобто порядок досягнення визначених стратегічних, оперативних і тактичних цілей.

Аналіз останніх досліджень i публікацій. Питання щодо досліджень оцінювання результатів діяльності підприємства, рівня ефективності управління, повноти i якості ресурсного забезпечення висвітлювали у своїх працях такі вчені, як П. Друкер, Р. Каплан, Д. Нортон, Д. Парментер та інші [1-3].

У роботі П. Друкера [1] запропонована концепція "Управління по цілям", яка дає змогу організації досягти успіху, коли керівники зосереджені на виконанні основних стратегічних завдань. До того ж індикаторами, що визначають рівень досягнення цілей, $\epsilon$ система ключових показників ефектмвності (від англ. Key Perfomance Indicator $\boldsymbol{K P I}$ ). У роботі [2] автори запропонували систему причинно-наслідкового зв'язку між стратегічними цілями, які відображують атрибути i фактори отримання намічених результатів, на основі фінансових та нефінансових показників, удосконалення внутрішніх бізнес-процесів, розвитку i 
мотивації персоналу. У монографії [3] визначаються способи розроблення та впровадження ключових показників ефективності за напрямами діяльності підприємства на різних рівнях управління, 3 яких деякі $\epsilon$ унікальними за специфікою оцінювання результатів діяльності цієї компанї.

У міжнародній практиці

використання $\boldsymbol{K P I}$ набуло широкого розповсюдження в економіці, сучасному бізнесі, управлінні людськими ресурсами та багатьох інших інноваційних підприємствах, основною метою яких $є$ отримання максимального прибутку - досягнення ключових факторів успіху. Терміни КПЕ та $\boldsymbol{K P I}$ - тотожні. Далі у статті використовується термін $\boldsymbol{K P I}$ як прийнято у міжнародній практиці. Проте у доступних публікаціях недостатньо уваги було приділено формуванню $\boldsymbol{K P \boldsymbol { I }}$ для воєнного (бюджетного) відомства.

Ключові показники ефективності [5] показники діяльності підприємства, які допомагають організації в досягненні стратегічних і тактичних (операційних) цілей. Використання $\boldsymbol{K P I}$ дає організації можливість оцінити поточний стан і оцінити перспективи реалізації визначеної стратегії.

Визначальними чинниками формування стратегічних цілей i завдань на етапі проведення оборонної реформи в Україні, які відображені у Державній Програмі розвитку Збройних Сил (ЗС) України на період до 2020 року [6], є професіоналізація 3С України, автоматизація процесів управління та обліку, перехід до системи оборонного планування на основі спроможностей, перехід до перспективної системи управління військами (силами) на основі нового розподілу функцій, завдань та повноважень, відповідно до стандартів, прийнятих у державахчленах НАТО.

Аналіз поточного стану та оцінка ступеня реалізації завдань Державної Програми розвитку 3С України в аспекті управління персоналом, створення умов для гарантованого та якісного комплектування ЗС особовим складом, спроможним виконувати завдання за призначенням, i його ефективне використання, потребує ретельного опрацювання та впровадження в автоматизовану інформаційно-аналітичну систему управління особовим складом ключових показників ефективності.
Мета статті. Обгрунтування пропозицій щодо розроблення ключових показників ефективності управління персоналом 3С України.

Виклад основного матеріалу. Головною умовою ефективного реагування на загрози національній безпеці України у військовій сфері, захисту суверенітету та територіальної цілісності й недоторканості України, є спроможність особового складу ЗС України виконувати покладені на нього завдання. Розвиток основних напрямів військової кадрової політики зумовлена необхідністю проведення оборонної реформи, що проводиться в умовах складної воєннополітичної обстановки та виконання завдання стосовно впровадження автоматизованої системи управління оборонними ресурсами (DRMIS - Defense Resource Management Information System) [7].

Реалізація основних аспектів кадрової політики залежить від обгрунтованого управління кадровими процесами, що дає змогу поєднати інтереси держави з інтересами кожної особистості, яка належить до системи кадрового менеджменту 3С України [8].

Система кадрового менеджменту (система управління персоналом) - сукупність цілей, завдань, функцій організаційної структури управління персоналом, взаємодії органів військового управління у процесі планування, обгрунтування, формування, прийняття та реалізації управлінських (кадрових) рішень.

Персонал 3С - особовий склад 3С та резервісти, які проходять службу у військовому резерві 3С.

Структурно-логічна схема обгрунтування, впровадження і використання $\boldsymbol{K P I}$ управління персоналом 3С України наведена на рис. 1 i містить такі етапи:

структуризація вихідних даних (блок 1);

формування СЗП, обгрунтування та розрахунок $\boldsymbol{K P I}$ (блок 2);

впровадження $\boldsymbol{K P I}, \quad$ формування

управлінських рішень, візуалізація КPI (блок 3).

Блок 1 (структуризація вихідних даних).

Аналіз світового досвіду [1-5]. Існують два підходи до оцінювання ефективності функціонування будь-якої системи:

перший - базується на співставленні розміру отриманого ефекту, тобто результату та суми витрат, які обумовили цей ефект (оцінка результативності функціонування системи);

другий - полягає у співвідношенні кінцевого корисного результату, який досягнуто у процесі функціонування системи, до заздалегідь запланованих бажаних показників відповідно до цілей організаціі. 


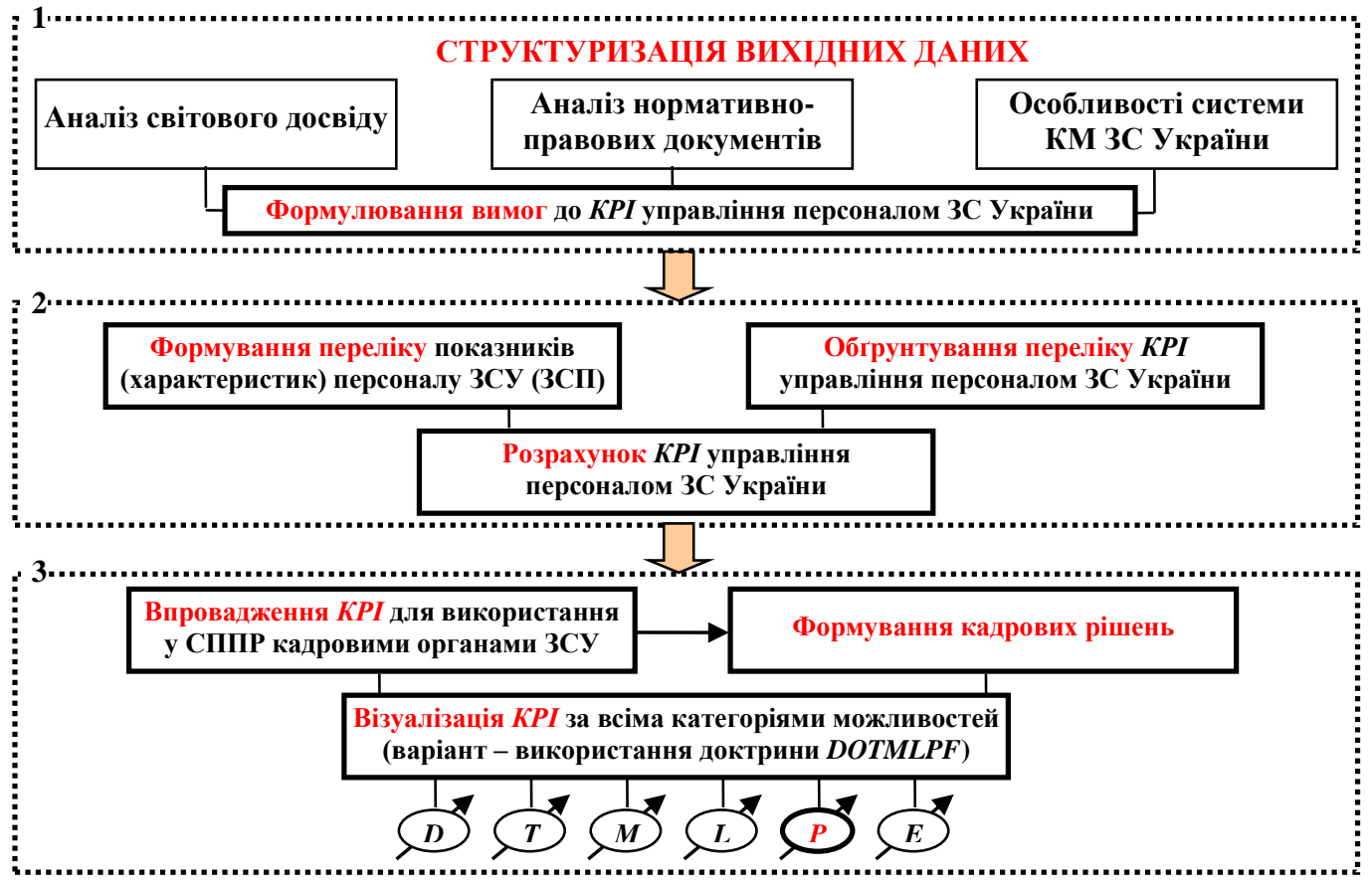

Рис. 1 Структурно-логічна схема формування і впровадження КРI

Ефективність менеджменту персоналу має такі складові: економічну, організаційну та соціальну.

Економічна ефективність управління персоналом - співвідношення результату функціонування системи і сукупних витрат на оплату праці та необхідного для цього обладнання. Важливою передумовою досягнення прийнятного рівня економічної ефективності $\epsilon$ забезпечення адекватного організаційного менеджменту персоналу.

Організаиійна ефективність управління персоналом характеризує ступінь використання потенційних можливостей колективу для виконання покладених на нього завдань i оцінюється показниками, які відображають стан комплектування 3С персоналом, спроможним виконувати завдання за призначенням, відповідно до набутих знань, навичок та досвіду. Організаційна ефективність управління персоналом характеризується показниками:

стан забезпечення потреб військових формувань ЗС України у персоналі за професіями, спеціальностями, посадами та освітньо-кваліфікаційними рівнями працівників;

ефективність використання робочого часу, кваліфікації та творчого потенціалу всіх категорій персоналу;

якість послуг (для підрозділів, що виконують функції забезпечення).

Поняття соиіальної ефективності включає вимоги гармонійного розвитку особистості кожного працівника, підвищення його кваліфікації, посилення соціальної активності, формування сприятливого клімату в колективі. Під час оцінювання соціальної ефективності необхідно враховувати такі соціально-психологічні аспекти: система мотивації; соціально-психологічний клімат в колективі; повноваження працівників i ïx відповідальність; кількість і якість міжособистісних комунікацій; гнучкість системи кар'єрного просування; авторитет керівника; ступінь задоволеності від виконуваної роботи; власна оцінка колективом відносин в організації.

Аналіз нормативно-правових документів. Основні підходи щодо запровадження системи кадрового менеджменту, залучення громадян України на військову службу, впровадження механізмів управління кар'єрою персоналу, його підготовки та утримання, основи комплектування ЗС України, створення умов для високоефективного використання військовослужбовців, підвищення ефективності кадрової роботи у військах (силах) визначені у Концепиії кадрової політики в ЗС України на період до 2020 року (далі - Конщепиія) [8]. У Концепції визначені основні завдання стосовно: розвитку системи кадрового менеджменту - всього 14 завдань, підготовки кадрів (для системи військової освіти) - 13 завдань, соціального та гуманітарного забезпечення персоналу 3С - 22 завдання.

Реалізація завдань за основними напрямами розвитку військової кадрової політики у ЗС спрямована на досягнення визначених показників стосовно:

досягнення

раціональнішого співвідношення категорій особового складу, 
приведення співвідношення посад офіцерського складу за рівнями військової освіти;

підвищення ефективності системи військової освіти через удосконалення навчально-матеріальної бази, практичного спрямування навчання, впровадження в навчальний процес передових методик підготовки, оптимізації мережі ВВН3;

підвищення в суспільстві престижу військової служби, подолання існуючої тенденції відтоку кваліфікованих спеціалістів, професійної адаптації військовослужбовців до цивільного життя.

Концепція зорієнтована на виконання оперативних цілей i завдань, визначених концептуальними та програмними документами оборонного планування у 2017 2020 роках.

Очікуваним результатом Оборонноі реформи є створення за принципами та стандартами, прийнятими в державах-членах НАТО, ефективних, мобільних, оснащених сучасним озброєнням, військовою i спеціальною технікою сил оборони зразка 2020 року, здатних гарантовано забезпечити оборону держави та адекватно i гнучко реагувати на воєнні загрози національній безпеці України, раціонально використовуючи на цім наявний потенціал (спроможності) та ресурси держави. План дій щзодо впровадження оборонної реформи у 2016 - 2020 роках (дорожня карта оборонної реформи) передбачає досягнення п'яти стратегічних цілей [6]. Основні цілі та завдання щодо удосконалення кадрового забезпечення прописані у Стратегічних цілях № 1 та № 5 .

Оперативна изіль 1.4 передбачає створення єдиної інформаційної системи управління оборонними ресурсами DRMIS завдання 1.4.8. Змістом цього завдання $€$ створення Єдиної інформаційної системи управління оборонними ресурсами, зокрема, управління особовим складом, яка відповідає стандартам, доктринам i рекомендаціям HATO.

Змістом Оперативної цілі 5.3. є забезпечення функціонування Державної системи мобілізації та мобілізаційної підготовки на основі базових європейських підходів (містить 4 завдання).

Оперативна иіль 5.4 - створення сучасної системи кадрового менеджменту містить 4 завдання.

Означені завдання містять певні заходи, кількісна характеристика ступеня виконання яких може використовуватися як критерій оцінки результату. Заходи щодо виконання означених завдань частково прописані у керівних документах та у фахових джерелах щодо змісту конкретного завдання.

\section{Особливості системи управління} персоналом 3С України. Вихідними даними для здійснення управління персоналом 3С України є результати оборонного планування, що здійснюється Головним управлінням оборонного планування Генерального штабу ЗС України. До того ж кадрову роботу щодо управління персоналом 3С України можна структурувати за такими компонентами: облік усіх категорій населення України щодо військового обов'язку; адміністрування персоналу; набір і розвиток персоналу; формування аналітичної звітності.

На сьогодні облік особового складу здійснюється згідно з керівними документами та ведеться за формами, перелік яких затверджено відповідними відомчими нормативними документами.

Компонента "Адміністрування персоналу” містить 20 підпроцесів, які можна розділити на групи:

прийняття на військову службу, роботу (усі категорії персоналу - усього 6 підпроцесів);

присвоєння військових звань i рангів державним службовцям, призначення на посаду та просування по службі персоналу всього 5 підпроцесів;

відпустки та відрядження (усі категорії кадрового резерву - усього 5 підпроцесів);

звільнення $з$ військової служби, роботи (усі категорії кадрового резерву - всього 4 підпроцеси).

Компонента "Набір та розвиток персоналу" містить 8 підпроцесів, 3 яких 4 передбачають врахування цілей, потреб і можливостей 3С та конкретної особи.

Компонента "Формування аналітичної звітності" містить 5 підпроцесів і передбачає використання актуальної бази даних i безпосередньо пов'язана 3 результатами оборонного планування.

За кожною компонентою кадрової роботи доцільно сформувати відповідні показники ефективності.

Формулювання вимог до КPI системи управління персоналом 3С України. Для збалансованості системи (набору) показників слід враховувати правило, з якого випливає, що в системі мають бути присутніми як процесні, так і проектні (загальні) показники.

Процесні показники відрізняються 
можливістю отримання їх актуальних значень у будь-який момент часу, тоді, як проектні показники отримують актуальні значення найчастіше під час закриття звітного періоду (етапу) проекту.

у своїй більшості організації складаються 3 множини підрозділів і цілого комплексу допоміжних сервісних відділів. Збалансовані показники, які розроблені на найвищому ієрархічному рівні організації (відомства), мають бути каскадовані на ii більш низькі рівні. У цьому разі стратегічна відповідність і синергізм (один 3 принципів стратегічно орієнтованої організації) стають невід'ємними їі рисами.

Загальні (проектні, запізнілі) КРI формуються зважаючи на керівні законодавчі та правові акти. Для кожного нижчого рівня управління доцільно формувати окремі КРI (процесні, оперативні, випереджальні), які пов'язані 3 цільовою установкою i повноваженнями визначеного рівня.

Зазвичай до кожного KPI ставиться низка формальних вимог [3]:

об'єктивність або повна формалізація обчислень;

простота обчислення;

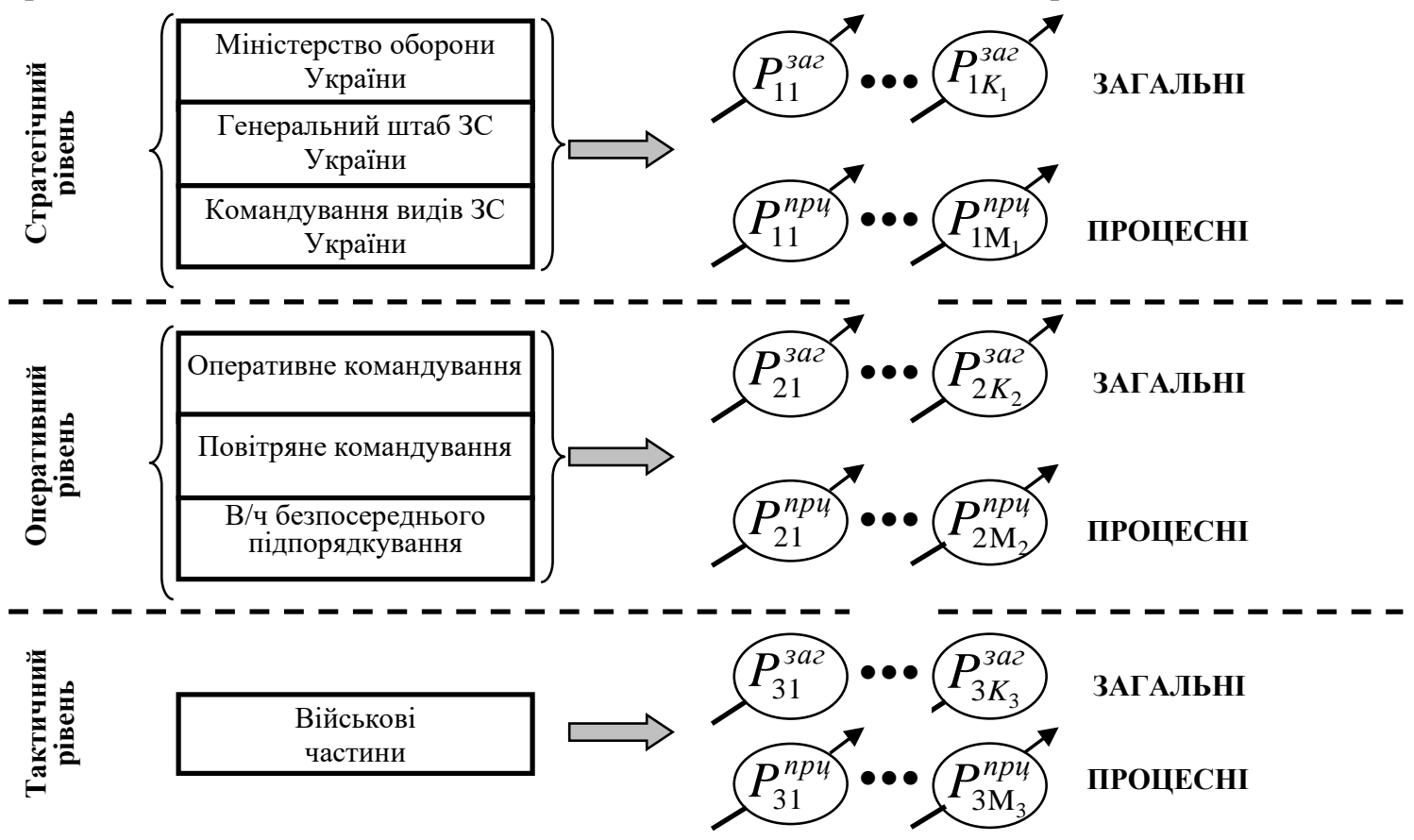

Рис. 2. 3СП управління персоналом 3С України

регулярність і потрібна частота вимірювань;

досяжність запланованого значення КPI (мета має бути реальною для досягнення iii співробітником або підрозділом);

орієнтованість на мету.

Крім формальних вимог до якості розроблюваних KPI існують і кількісні вимоги до них. Засновник системи оцінювання ефективності діяльності за допомогою ключових показників Д. Парментер, дає такі рекомендації [2, 3]: не більше 10 показників для організації в цілому; 5-7 показників для кожного її підрозділу; від 3 до 5 для кожного співробітника.

Таким чином, КРI мають сприяти реалізації проміжних і кінцевих цілей, а всі індикатори - чіткий фізичний зміст та можливість оперативного розрахунку. Індикатори бувають:

якісними (добре, задовільно, погано);

кількісними (у вигляді термінових i фінансових витрат, обсягу послуг, кількості задіяних людей, значення рейтингу або кількості балів тощо).

Структура збалансованої системи показників наведена на рис. 2.
Блок 2 (формування обгрунтування та розрахунок $\boldsymbol{K P I}$ ).

Формування переліку показників (характеристик) персоналу 3С України збалансованої системи показників.

Збалансована система показників (ЗСП, англ. balanced scorecard, BSC) - інструмент стратегічного управління результативністю - частково стандартизована форма звітності, що дає змогу менеджерам відстежувати виконання завдань співробітниками. У широкому сенсі ЗСП - це концепція перенесення і декомпозиції стратегічних цілей для планування операційної діяльності та контролю їх досягнення, механізм взаємозв'язку стратегічних планів i рішень $з$ поточними завданнями. 
Перелік показників (характеристик) персоналу ЗС України доцільно представити за напрямами кадрової роботи:

\section{організаційна складова:}

укомплектованість військовослужбовцями, які проходять військову службу за контрактом по категоріям - 8 показників;

штатна структура - 11 показників;

показники оцінювання результатів проведення процедур підбору, розстановки та призначення особового складу на посади, звільнення 3 військової служби, залучення військовослужбовців до участі в операції Об'єднаних Сил (ООС) - 9 показників;

показники надходження особового складу до органів управління та військових частин (підрозділів) військ (сил) від різних джерел формування персоналу ЗС України 13 показників;

показники щодо підготовки персоналу 3С України (набуття фахових за посадою компетентностей) - більше 70-ти показників; показники щодо вибуття персоналу ЗС України 3 різних причин на поточну (визначену) дату - більше 80-ти показників; показники щодо прогнозування потреб комплектування військовослужбовців (по категоріях за військовим званням) по групах BOC - 29 показників;

показники виконання вимог Закону України "Про очищення влади" - чисельність військовослужбовців у відсотках, що пройшли перевірку, зокрема опитування за допомогою поліграфа на визначені контрольні дати оцінювання (місяць, рік) - 4 показники; показники поточної чисельності військовослужбовців (по категоріях за військовим званням), а також військовослужбовців, які проходять службу у військовому резерві ЗС України у відсотках, до показників чисельності військовослужбовців організаційної структури перспективного складу військ (сил), відповідно до сценаріїв застосування ЗС України, за кризовими ситуаціями, що загрожують національним інтересам України у військовій сфері, визначених під час проведення оборонного огляду - більше 50 -ти показників;

соціальна складова:

$$
E_{\text {екон }}(H)=\frac{H_{\text {ynp/nерс }}}{H_{0}} \times 100 \% \text { або } E_{\text {екон }}(F)=\frac{F_{y n p / n е р с}}{F_{0}} \times 100 \%,
$$




\begin{tabular}{|c|c|}
\hline №ח/II & НАПРЯМИ РОЗВИТКУ ВІЙСБКОВОЇ КАДРОВОЇ ПОЛТТИКИ \\
\hline $\mathbf{I}$ & $\begin{array}{c}\text { Удосконалення системи управління персоналом шцодо залучення громадян України } \\
\text { на військову служсбу }\end{array}$ \\
\hline 1.1 & $\begin{array}{l}\text { Посилення мотивації громадян до проходження військової служби за контрактом, підвищити престиж } \\
\text { військової служби, конкурентоспроможність професії військовослужбовця (в/с) на ринку праці України: } \\
\text { - здійснити комплекс заходів, спрямованих на посилення мотивації стосовно проходження військової } \\
\text { служби за контрактом (грошове та медичне забезпечення, отримання житла тощо); } \\
\text { - створити сприятливі умови для навчання військовослужбовців та здобуття ними якісної освіти, } \\
\text { передбачивши можливість отримання освіти без відриву від виконання обов’язків військової служби, } \\
\text { зокрема за цивільними спеціальностями }\end{array}$ \\
\hline 1.2 & $\begin{array}{l}\text { Створення належних умов для комплектування ЗС кваліфікованим персоналом, реалізуючи одночасно } \\
\text { принцип екстериторіальності: } \\
\text { - створити єдиний державний реєстр військовозобов’язаних для забезпечення військового обліку } \\
\text { громадян України; } \\
\text { - сформувати в необхідних обсягах військовий резерв для призначення на посади до військових частин } \\
\text { бойового складу ЗС для їх оперативного доукомплектування особовим складом (о/c) }\end{array}$ \\
\hline 1.3 & $\begin{array}{l}\text { Здійснення заходів із підвищення ефективності органів військового управління, військових частин і } \\
\text { військових комісаріатів: } \\
\text { - постійний моніторинг вакантних посад, необхідних термінів їх укомплектування через впровадження у } \\
\text { практичну діяльність сучасних ІТ, автоматизації процесів обліку людських ресурсів; } \\
\text { - забезпечення керованості процесу комплектування } 3 \text { урахуванням реальної потреби військ (сил) у } \\
\text { конкретних військово-облікових спеціальностях, передусім -у комплектуванні бойових військових частин } \\
\text { 3С; } \\
\text { - оптимізація організаційно-штатної структури органів, які займаються залученням громадян на } \\
\text { військову службу за контрактом, через створення на базі військових комісаріатів територіальних центрів } \\
\text { комплектування та соціальної підтримки; } \\
\text { - відбір громадян на військову службу за контрактом та службу у військовому резерві з урахуванням } \\
\text { встановлених вимог до кандидатів (стан здоров’я, фізичною підготовленість, рівень освіти та морально- } \\
\text { психологічні якості) }\end{array}$ \\
\hline II & $\begin{array}{r}\text { Розвиток системи кадрового менеджсменту } \\
\text { (спрямований на оптимальне забезпечення потреб 3С в особовому складі) }\end{array}$ \\
\hline 2.1 & $\begin{array}{l}\text { Нарощування показників укомплектованості військовослужбовців за контрактом передусім бойових } \\
\text { посад, що визначають боєздатність частин (підрозділів) }\end{array}$ \\
\hline 2.2 & Удосконалення планування кадрових ресурсів перспективного складу військ (сил) \\
\hline 2.3 & $\begin{array}{l}\text { Приведення структури особового складу (з відповідними кількісно-якісними показниками та } \\
\text { співвідношенням його категорій) відповідно до потреб ЗС і вимог Концеепциї }\end{array}$ \\
\hline 2.4 & $\begin{array}{l}\text { Набуття потрібної чисельності персоналу до показників чисельності військовослужбовців організаційної } \\
\text { структури перспективного складу військ (сил). }\end{array}$ \\
\hline 2.5 & $\begin{array}{l}\text { Забезпечення ефективного службового використання військовослужбовців, які мають відповідний рівень } \\
\text { військової освіти, науковий ступінь (вчене звання), пройшли підготовку за кордоном, є учасниками } \\
\text { бойових дій, отримали досвід під час проведення ООС тощо }\end{array}$ \\
\hline 2.6 & $\begin{array}{l}\text { Формування професійного сержантського i старшинського складу } 3 \text { С, який здатний забезпечити } \\
\text { виконання завдань щодо виховання та навчання особового складу }\end{array}$ \\
\hline 2.7 & Створення ефективної системи управління кар’єрою військовослужбовців \\
\hline III & Удосконалення підготовки кадрів \\
\hline 3.1 & $\begin{array}{l}\text { Приведення змісту і технології навчання військових фахівців відповідно до сучасних завдань ЗС та вимог щодо } \\
\text { їх підготовки (досвід бойових дій, передові методики підготовки армій держав-членів НАТО, впровадження } \\
\text { технології дистанційного навчання) }\end{array}$ \\
\hline 3.2 & $\begin{array}{l}\text { Оптимізація мережі вищих військових навчальних закладів (ВВНЗ), наукових закладів і установ, їх } \\
\text { організаційно-штатних структур }\end{array}$ \\
\hline 3.3 & $\begin{array}{l}\text { Визначення обсягів державного замовлення на підготовку та підвищення кваліфікації військових фахівців за } \\
\text { всіма ступенями вищої освіти, рівнями військової освіти та оптимізованим переліком спеціальностей їх } \\
\text { підготовки з урахуванням перспективної структури }\end{array}$ \\
\hline 3.4 & Удосконалення підготовки громадян України за Програмою підготовки офіцерів запасу \\
\hline 3.5 & $\begin{array}{l}\text { Удосконалення системи підвищення кваліфікації офіцерського складу, працівників ЗС України, сержантського і } \\
\text { старшинського складу }\end{array}$ \\
\hline 3.6 & Розвиток мовної підготовки та системи вивчення іноземних мов військовослужбовцями та працівниками ЗС \\
\hline IV & Соціальне та гуманітарне забезпечення персоналу ЗС України \\
\hline 4.1 & Оптимізація системи грошового забезпечення в/с відповідно до умов проходження служби \\
\hline 4.2 & Удосконалення систем стимулювання військової майстерності \\
\hline 4.3 & $\begin{array}{l}\text { Здійснення заходів щодо гарантованого забезпечення в/с службовим житлом та виплати, за їх бажанням, } \\
\text { грошової компенсації за належні їм для отримання жилі приміщення }\end{array}$ \\
\hline 4.4 & Розвиток системи медичного і санаторно-курортного забезпечення персоналу ЗС \\
\hline 4.5 & $\begin{array}{l}\text { Поліпшення професійної адаптації в/с, які підлягають звільненню, та осіб, звільнених з військової служби: } \\
\text { - створення системи зміни військової кар'єри на професійну цивільну для реформування існуючої системи } \\
\text { соціальної та професійної адаптації в/с ЗС України; } \\
\text { - розроблення програми соціальної та професійної адаптації в/с }\end{array}$ \\
\hline
\end{tabular}


де $H_{\text {ynp/nерс }}$ - загальна кількість персоналу 3С

України, який працює у системі кадрового менеджменту;

$F_{\text {упр/перс }}$ - фінансові витрати на утримання персоналу 3С України, який працює у системі кадрового менеджменту;

$H_{0}$ - загальна чисельність персоналу 3С України;

$F_{0}$ - фінансові витрати на утримання персоналу ЗС України.

2. Організаиійна

ефективність

управління персоналом оцінюється за допомогою кількісного аналізу змін стану укомплектованості військ (сил). Наведемо приклади формування ключових показників ефективності стосовно вимог, які визначені документом [8].

Досягнення раціональнішого співвідношення категорій особового складу відповідно до їх структури та штатної чисельності (п.2.3 Табл. 1), а саме:

офічерський склад - до 25\%, 3 них посад вищого офіцерського складу - 0,3\%; старшого офіцерського складу - $43 \%$; молодшого офіцерського складу $-56,7 \%$;

солдати і сержанти - до $70 \%$;

курсанти - $5 \%$.

Відсоток чисельності посад офіцерського складу $P_{o \phi}(t)$ до загальної чисельності посад кадрових військових ЗС $H_{\Sigma}(t)$ на визначені контрольні дати оцінювання $t$ :

$$
P_{o \phi}(t)=\left(\sum_{i} H_{i}(t) / H_{\Sigma}(t)\right) \times 100 \%, i=\overline{1,3}
$$

де $H_{1}(t), \ldots, H_{3}(t)$ - чисельність посад вищого, старшого і молодшого офіцерського складу на визначені контрольні дати оцінювання $t$ відповідно.

$$
H_{\Sigma}(t)=\sum_{i} H_{i}(t), i=\overline{1,5} \text { - загальна }
$$

чисельність посад кадрових військових 3С на визначені контрольні дати оцінювання;

Відсоток чисельності посад вищого, старшого та молодшого офіцерського складу $P_{1}, P_{2}, P_{3}$; рядового та сержантського складу
$P_{4}$; курсантів ВВНЗ $P_{5}$ до загальної чисельності посад кадрових військових $3 \mathrm{C}$ на визначені контрольні дати оцінювання:

$$
P_{i}(t)=\left(H_{i}(t) / H_{\Sigma}(t)\right) \times 100 \%, i=\overline{1,5} H_{4},
$$

де $H_{4}, H_{5},-$ чисельність посад рядового i сержантського складу; курсантів ВВН3 відповідно.

Показники $P_{o \phi}(t), P_{1}(t), \ldots, P_{3}(t)$ можна

вважати ключовими показниками щодо досягнення раціонального співвідношення посад категорій особового складу. До того ж значення наведених показників на поточні (проміжні дати) можна вважати процесними показниками, а значення на кінець 2020 року перетворює їх на загальні.

Ключовими показниками результатів діяльності системи управління персоналом щодо набуття потрібної чисельності персоналу до показників чисельності військовослужбовців організаційної структури перспективного складу військ (п. 2.4 табл. 1) $є$ показники поточної чисельності військовослужбовців (по категоріях за військовим званням, на визначену дату) та військовослужбовців, які проходять службу у військовому резерві ЗС України у відсотках, до показників потрібної чисельності військовослужбовців організаційної структури перспективного складу військ (сил), відповідно до сценаріїв застосування ЗС України, за кризовими ситуаціями (п. 2.4 табл. 1 ), що загрожують національним інтересам України у військовій сфері, визначених під час проведення оборонного огляду. Для розрахунку потрібні такі вихідні дані:

прогнозовані кризові ситуації $z(z=\overline{1, Z})$ та можливі сценарії їх розвитку $x_{z}\left(x_{z}=\overline{1, X_{z}}\right)$;

військові формування $k \quad(k=\overline{1, K})$, які мають реагувати на ситуації (сценарії);

перспективна організаційна структура військових формувань;

наявне кадрове забезпечення по категоріях за військовим званням.

Загальний вираз для розрахунку ключових показників можна подати у вигляді

$$
P\left(z / x_{z}, H_{i}, t, k\right)=\left(\frac{H_{i}(t, k)}{H_{i, \text { nepcn }}\left(z / x_{z}, k\right)}\right) \times 100 \% ; \mathrm{i}=2-4,6 ; z=\overline{1, Z} ; x_{z}=\overline{1, X_{z}} ; k=\overline{1, K} .
$$

де

$$
H_{6} \text { - чисельність }
$$

посад

військовослужбовців, які проходять службу у військовому резерві.

Аналогічно визначається решта $\boldsymbol{K P I}$, які формуються з вимог керівних документів для кожного рівня управління персоналом ЗС. Зіставлення обраних показників на різні дати визначення дає змогу зрозуміти динаміку 
наближення конкретного ключового показника до запланованого рівня.

Блок 3 (упровадження $\boldsymbol{K P I}$, формування управлінських рішень, візуалізація $\boldsymbol{K P I ) . ~}$

Упровадження $\boldsymbol{K P I}$ та формування управлінських рішень $є$ самостійними наукоємними завданнями. Детальний опис порядку їх виконання виходить за межі цієї статті. Проте слід зазначити, що обов'язковою умовою застосування $\boldsymbol{K P I} \epsilon$ проведення автоматизації процесів управління персоналом для отримання адекватних вихідних даних для розрахунків.

Візуалізація KPI управління

персоналом. Візуалізація аналітично обробленої інформації у зручній, сприятливій до усвідомлення формі допомагає швидко зорієнтувати посадову особу кадрового органу управління про забезпеченість персоналом та динаміку змін за період для прийняття обгрунтованого управлінського рішення. На сьогодні існують комплекси програмних продуктів, які мають потужний інструментарій для створення гнучких звітів та представлення аналітичних даних у зручному для користувача вигляді. На рис. 1 показана індикація за всіма категоріями спроможностей відповідно до доктрини DOTMLPF [10] (D Doctrine - доктрина; O Organization - організаційна структура; T Training - підготовленість; M Materiel ресурси; L Leadership - керівництво; $\boldsymbol{P}$ Personnel - особовий склад; F Facilities інфраструктура). Детально панелі візуалізації розглянуто у роботі [10].

Висновки. Сукупність викладених положень свідчить про актуальність досліджень у даній предметній галузі. Розроблення та впровадження у діяльність кадрових органів ключових показників ефективності для оцінювання складових елементів системи кадрового менеджменту вимогам спроможностей, аналіз та правильний підбір критеріїв дадуть змогу підвищити обгрунтованість рішень, тобто ефективність управління.

Використання $\boldsymbol{K P I P}$ у відповідній інформаційно-аналітичній системі, як складової Єдиної інформаційної системи управління оборонними ресурсами (DRMIS), підвищить ефективність прогнозування потреб і якість комплектування 3С особовим складом відповідно до реальних і потенційних загроз у сфері національної безпеки і оборони, моніторингу поточного стану забезпечення кадровими ресурсами.

Подальші дослідження доцільно зосередити на розробленні повного переліку $\boldsymbol{K P I}$ управління персоналом для надання їм нормативного статусу i впровадження у практику діяльності кадрових органів (наприклад, надання планових звітних документів). Крім того, окремих досліджень потребують питання вироблення кадрових рішень з використанням $\boldsymbol{K P I}$.

\section{СПИСОК ВИКОРИСТАНОЇ ЛІТЕРАТУРИ}

1. Питер Ф. Друкер. Энциклопедия менеджмента. // С. Петербург. изд. Вильямс - 2008 / ISBN 978-58459-0588-8, 0-0662-1087-9.

2. Robert S. Kaplan , David P. Norton. The Balanced Scorecard: Translating Strategy into Action.// the USA - 1996 / ISBN 0-87584-651-3/

3. Дэвид Парментер. Ключевые показатели эффективности. Разработка, внедрение и применение решающих показателей. // M Олимп-бизнес - 2007 / ISBN: 978-5-9693-0106-1.

4. Приходченко Л. Л. Щодо складності застосування показників оцінювання ефективності державного управління: теорія i практика. // Державне будівництво. № 12009 р. - Режим доступу:

http://nbuv.gov.ua/UJRN/DeBu_2009_1_9.

5. Ключові показники ефективності. Матеріал з Вікіпедії. [електронний ресурс]. / режим доступу: https://uk.wikipedia.org/wiki/Ключовi_показники_ ефективності.

6. Указ Президента України від 22.03.2017 № 73/2017 "Про рішення Ради національної безпеки і оборони України від 29.12.2016 року “Про Державну програму розвитку ЗС України на період до 2020 року”.

7. Указ Президента України від 20.05.2016 № 240/2016 “Про рішення Ради національної безпеки і оборони України від 20.05.2016 року "Про Стратегічний оборонний бюлетень України".

8. Наказ Міністерства оборони України від 26.06.2017 № 342 “Про затвердження Концепції військової кадрової політики у ЗС України на період до 2020 року".

9. DOTMLPF. Матеріал з Вікіпедії. [електронний peсурс]. / режим доступу: https://en.wikipedia.org/ wiki/DOTMLPF.

10. Прокопенко О. С. Інформаційні панелі, як засіб підвищення ефективності управління оборонними ресурсами. / Рибидайло А. А., Бондарчук С. В. Галаган В. І. // Стаття. Збірник наукових праць ЦВСД НУОУ ім. І. Черняховського. - К :№ 3 (55). - 2015 p. - C. 119. - 124. ISSN 2304-2699. 
Рыбыдайло А. А., к.т.н., с.н.с.;

Прокопенко А. С.;

Турейчук А. Н., к.т.н.;

Руденская Г. В.

Центр военно-стратегических исследований Национального университета оборони Украины имени Ивана Черняховского, Киев

Ключевые показатели управления персоналом вооружённых сил

Резюме. Рассмотрены вопросы обоснования и формирования ключевых показателей эффективности управления персоналом Вооруженных Сил Украины.

Ключевые слова: ключевой показатель эффективности; система кадрового менеджмента; персонал вооруженных сил; DRMIS.

A. Rybydajlo, PhD (Technical), senior researcher;

A. Prokopenko;

A. Tureychuk, PhD (Technical);

G. Rudenska

Center for Military and Strategic Studies of the National Defence University of Ukraine named after Ivan Cherniakhovskyi, Kyiv

Key Indicators of Armed Forces Personnel Management

Resume. The issues of substantiation and formation of key indicators of personnel management efficiency of the Armed Forces of Ukraine are considered.

Keywords: key performance indicator; personnel management system; military personnel; DRMIS. 